\title{
Teaching and Learning Using Computers: How Should We Tread on Its' Changing Technology?
}

\author{
http://dx.doi.org/10.3991/ijet.v9i5.3943 \\ Mohd Sazali Khalid ${ }^{1}$, Edi Sutoyo ${ }^{2}$, Mungad ${ }^{2}$, Eka Novita Sari ${ }^{3}$, and Tutut Herawan ${ }^{2}$ \\ ${ }^{1}$ University of Tun Hussein Onn Malaysia, \\ ${ }^{2}$ University of Malaya, Kuala Lumpur, Malaysia \\ ${ }^{3}$ AMCS Research Center Yogyakarta, Indonesia
}

\begin{abstract}
Children learn quickly from their own parents and as they grow up computers offer more learning options. However they would learn better if the lessons are properly constructed using cognitive, constructivist, collaborative and technical education principles i.e., incorporating mathematics lessons on the computers. This paper reports an 'experience' gained by a veteran mathematics teacher in building a courseware called CDiCL using ADDIE principles. The quasi-experimental research was run in Polytechnic Kota Bharu PKB, Kelantan under Ministry of Higher Education (MoHE) Malaysia among 137 students at Certificate Engineering students in March 2006 among 4 different groups within 8 weeks. It was discovered $C D$ only group scored the highest gain score of 6 points (difference in Post Test and Pre Test) while CL (Collaborative Learning) only group scored the least 2 points. From clinical interview, many students failed to understand mathematics from the courseware because of English and behavior problems among participants but some leaders in CL group gained leadership experience demanding soft skills in understanding peers' limited skills and anxiety at presenting mathematics problem solving. The study concluded with a framework / rubrics for teachers to be effective dealing with mixed ability group of students learning mathematics on computers.
\end{abstract}

Index Terms-Teaching and learning; Computer; CDiCL; ADDIE principles.

\section{INTRODUCTION}

Human has the ability to think, learn, agreeing and rejecting to any idea at the same time. With this ability man had developed many pyramids in Eygpt to Petronas Towers in Kuala Lumpur and Borobudur Temple in Yogyakarta. In these constructions, men took many years to learn and apply knowledge and skills successfully. However, men accepted that mistakes were a part of the learning processes. This came in the form of death tolls, money and time. Slowly men began to realize that they need to be careful in building challenging projects without repeating the same errors. This is called education. Human is changing through education. From history, man learns from their teachers. This was a period where the teacher was the main actor. Now as the year 2013 proceeds towards the month of June, teachers are mere facilitators because many children learns many skills both formally at schools and informally from their own parents, siblings, TV and computers at home.

The research issue here is what should a teacher guide / what form of facilitation is going to help the students gaining skills and knowledge of mathematics on the computer/internet? What yardstick are being used in deciding the level of facilitation's success incorporating the breadth and the depth we are going to help our students and where must we stop so that our students are able to explore the knowledge by themselves. The answer could be something associated with the amount of time a teacher has knowing in advance that a standard Malaysian classroom have more than 30 students each per lesson. Therefore we must be able to produce somehow a semi structured framework / rubrics of a teacher teaching mathematics on the computers.

This paper reports an 'experience' gained by a veteran mathematics teacher in building a courseware called CDiCL using ADDIE principles. The quasi-experimental research was run in Politeknik Kota Bharu, Kelantan MOHE among 137 students at Certificate Engineering students in March 2006 among 4 different groups within 8 weeks. It was discovered CD only group scored the highest gain score of 6 points (difference in Post Test and Pre Test) while CL (Collaborative Learning) only group scored the least 2 points. From clinical interview, many students failed to understand mathematics from the courseware because of English and behavior problems among participants but some leaders in CL group gained leadership experience demanding soft skills in understanding peers' limited skills and anxiety at presenting mathematics problem solving. The study concluded with a framework / rubrics for teachers to be effective dealing with mixed ability group of students learning mathematics on computers.

In view of this, this paper is organized in five parts. First part dwells on history of education in Malaysia, second on computers in education, third construction of courseware called CDiCL, fourth experience using a courseware in PKB and UTHM and finally it concludes with recommendation and its future use in Malaysian Technical University Network MTUN Malaysia.

\section{History OF EDUCATION IN MALAYSIA}

After 1969, Malaysians start their education at the primary school for 6 years [1]. They conclude their primary education with a public examination called UPSR (Ujian Penialian Sekolah Rendah). Good students are selected to join Science Schools throughout the country based from UPSR and their track records in co-curriculum activities. Next is the secondary school education that took another 5 years. Here the students faced two major examinations known as PMR (Penilaian Menengah Rendah) at age 15 
and SPM (Sijil Pelajaran Malaysia) at age 17. From SPM, the students proceed to tertiary educations such as learning specific skills to earn their living such as certificate, diploma and degree engineering and business studies. Once they graduate from a Malaysian Technical University Network (MTUN) like UTHM the students are about age 24 years old.

Smart schools came into Malaysian educational system in mid 1990's and this was used as the basis by the government in promoting Multimedia Super Corridor (MSC) in Cyberjaya, Malaysia. MSC has a specific objective so that many powerful computer companies like Micro Soft will establish their operations here and this can be done when smart schools graduates can be channeled into those companies successfully. Another aim was that the government wanted Malaysia to catch fast the trend set by Indian and Chinese by outsourcing jobs by Apple and IBM in the early 2000's. Indian managed to capture big chunk of this jobs because their medium of instruction was English through and through after their independence in 1945. In Malaysia, learning in smart schools can be done considering different learning modalities in which students learn, such as visual-auditory-kinesthetic, left brain/right brain and multiple intelligences $[2,4,5]$.

At this point there was a medium of instruction at schools between English and Malay. Mahathir forced all science and mathematics at schools ranging from primary to secondary education be taught in English from 2002 to 2011. However, it was suddenly stopped because rural Malays were reported to be falling deeper and deeper and stayed away from science technology courses after SPM [1].

The characteristics of a smart school are there are qualified teachers who can deliver lessons on the computers respectively [2]. They can accommodate and support diverse needs by students in terms of rich learning experiences. This teacher obtained the computer skills at their university education and successfully undergone some competent courses throughout their teaching career. Their experience will scaffold the correct amount of help in learning on computers so that the students feel more confident and comfortable in taking risks, and by doing so they march towards becoming independent learners. Next characteristics is a smart school is able to practice many kinds of administration work like daily attendance, teachers' participation of various level of upgrading courses and semester assessment and evaluation by the help of a dedicated computer software. Other administration includes management of library books by staff and student respectively. Of course at the end of the year, most of the students must perform very well as compared to nonsmart schools in SPM examinations. SPM is equivalent to GCSE ' $O$ ' levels in United Kingdom. After SPM, most students aged $18+$ and they are pursuing into tertiary educations in multi-disciplined fields locally or abroad. On the other hand, if there are students who experienced learning difficulties, and students with exceptional abilities who warrant different kinds of support, smart school facilities could cater that too through technology.

After the success of smart schools in the year 2000's, 25 cluster schools throughout the country was introduced into the Malaysian education map. Cluster schools created autonomy in the school's daily administration and financial aspect. Many headmasters wanted their school to be a cluster school so that they can enjoy at least three benefits called they can hire any staff as they like to upgrade their overall academic performance, manage the money appropriately that seemed beneficial to the school well being both physically and culturally and of course all staff can enjoy attending better upgrading courses in Kuala Lumpur and some form of travel. An Islamic college in Klang, Selangor managed to do some collaborative work with its counterpart in Australia in 2011 through this cluster school flagship. In order to get cluster school recognition, a school must prove beyond doubts that it has a niche area in either academic or co-curriculum field within a span of time. Examples Johor Science School is recognized in sports hockey, English College Johor in rugby and Zainab School Kelantan in debating contests at interstate levels.

In Malaysia, we took Cambridge University England as the yardstick towards academic excellence. As a result, the students learn many subjects including mathematics which was regarded as the most challenging subject in Malaysia [3]. According to a report by TIMMS [20] that Malaysian children at the age of 14 did not excel highly as compared to their counterparts in Singapore and Japan [20]. Close analysis revealed two difficulties - first, language and secondly, poor attitude of students and teachers towards science and mathematics subjects using English as the medium of instruction. Now Malay Language is increasingly used in teaching mathematics and sciences beginning 2013. Western countries like England, Germany and Asian power house like Japan did not face any problem in the medium of instruction because from history their technology supports their strength in learning using their own mother tongue $[4,15]$.

One of the tertiary educations in Malaysia that offered post SPM holders with semi-professional courses is Polytechnic Education System (MOHE) that specializes on certificate and diploma engineering and business studies. Yearly the polytechnic receives more than 50,000 applications but they can only accept 15,000 students. Certificate engineering program takes 2 years while Diploma Engineering takes 3 years and these programs are run in 30 polytechnics across the country. Each program offers an Industrial Training attachment with industries and government / nongovernment establishments [21]. From 2011, three premier polytechnics in Ipoh, Johor Baharu and Shah Alam were promoted in conducting Advanced Diploma program. From tracer study in 2007, most polytechnic graduates got jobs within 6-9 months after graduation. The education system in the polytechnics runs on a semesterly basis. Every year there are 2 semesters that has 15 weeks each. Their program started in January and July every year. During 2002 to 2006, MOHE seriously tried to introduce learning of mathematics, sciences and engineering subjects using well built modules that was constructed by their own experts throughout the country. One important tool used in polytechnics (MOHE) is the computers. Now internet came along with the computers.

\section{COMPUTERS IN EDUCATION}

Computers and internets offer many benefits to us. One of them is learning many skills directly using wellconstructed courseware and software. In 1995 Malaysia introduced Multimedia Super Corridor in Cyberjaya and to accelerate its progress, smart schools and Multimedia University were put into the Malaysian education system. About 20-30 schools were selected to adopt smart school concept. Many trainings were given to upgrade the teach- 
ers' skills and competencies so that their product (students) is more competent than normal schools. Smart schools have integrated management system that controls teachers' and students' attendance and examination results incorporating item analysis in each subject. Since then, Malaysia becomes the education hub in this Asian region.

It is a well-known fact that today's generation love to use mobile 24/7. Young children pick up the computer skills faster than adults because they do not have to worry repairing while the senior citizens are slow in adopting technology because of various anxieties. As teachers it would be better to find a point where the teaching style suits better to the learning style of their students [5]. Learning style is defined as how the students used certain cognitive strategy consistently regarding problem solving. Thus we have shallow and deep learning issues between on-line and conventional learning. Edutainment is a 'religion' now where the children learn, the adults do business and at the same time they got entertainment with computers [6]. A web site would be popularly used by students if it addresses the issues of accessibility, interesting and relevance contents in Nielson and Lorenger, 2006 as cited by Hazwani $[7,21]$.

\section{A. Shallow Learning versus Deep Learning}

Mobile learning leads to shallow learning because the users believe there are always answers to any problems posed by their teachers at school. They lack experience of solving mathematical problems by themselves for days $[14,15,16]$. Now all problems could be solved with the click of a mouse if they work collaboratively with their peers using e-mails $[17,18,19]$.

Lacking experience in solving problems on their own produce create many bad episodes where many IT workers hop from a job to another. According to MOE-Intel, 2008 report, some teachers did not like teaching using computers because it was difficult to keep abreast on modern technology and courseware products. They missed the point where multimedia (text, graphic, animation, video, sound, teaching system and support on computers) could make learning more interesting for at-risk students $[5,8]$. Now the parents have very high expectation from their children as far as examination is concerned. This is based on the monthly budget spent on education including tuition classes. Due to this, many parents help tuition classes to flourish directly/ indirectly and subscribe online tuition for their children. The message is clear - online learning is the in thing now.

\section{COURSEWARE DEVElopment}

This courseware was built based on item and error analysis which was done in few important SPM examination papers from year 2000-2004. Table 1 below shows some 'cancer' among teachers and students in mathematics.

We classified the errors into 5 categories called slips (careless mistakes), negative sign symbols, change side change sign, incorrect concept and transposing.

There are some interesting issues discovered from Table 1 above. First, the students regard negative signs as something irrelevant. From our experience, many students failed at higher mathematics especially calculus because of negative sign problems. Secondly, incorrect mathematical concept that was found rampantly made if this remained unchecked would lead to more serious problem during their university education especially in engineering disciplines. Thirdly, from clinical interview conducted by the first author, the marking scheme of elementary mathematics in Malaysia was too lenient and as such this negative signs grow bigger and bigger among the students.

This courseware was constructed to address the above problem. We were thinking perhaps we must produce a courseware that provides 'drill and practice 'plus discus-

TABLE I.

SOME “CANCER” AMONG TEACHERS AND STUDENTS IN MATHEMATICS

\begin{tabular}{|c|c|c|}
\hline Types of Errors & Examples & Remarks (if any) \\
\hline Slip-careless mistakes & $\begin{array}{l}\text { Example } \\
\frac{2}{4}=2\end{array}$ & $\begin{array}{l}\text { Some errors are resulted from direct lifting from } \\
\text { the exam paper onto the answer book. There was } \\
\text { a lapse between ' } 1 / 2 \text { ' in the brain and ' } 2 \text { ' as put } \\
\text { by the students on papers. }\end{array}$ \\
\hline Negative sign symbols & $\begin{array}{l}\text { Example } \\
2 x-4 x+2 y-y=2 x+y\end{array}$ & They missed the 'negative sign' at ' $-2 x$, \\
\hline Change side - Change sign & $\begin{array}{l}\text { Example } \\
1-2 x=2-x \\
-2 x+x=2-1 \\
x=1\end{array}$ & $\begin{array}{l}\text { They put the like and unlike terms correctly i.e., } \\
\text { those that have ' } x \text { ' and solid counting number } \\
\text { only onto } 2 \text { different sides next to the 'equals' } \\
\text { sign }\end{array}$ \\
\hline Transposing & $\begin{array}{l}\text { Example } \\
\frac{1}{x}=4 \\
1=4 x \\
x=-\frac{1}{4}\end{array}$ & $\begin{array}{l}\text { They use cross multiplication. It seems that } \\
\text { 'negative signs' are rampantly used without any } \\
\text { serious meaning. }\end{array}$ \\
\hline Incorrect concept & $\begin{array}{l}\text { Example } \\
\begin{array}{l}3 \frac{1}{3}=3+\frac{1}{3} \\
3 x-3=3+x-3=x\end{array}\end{array}$ & Incorrect concept between $31 / 3$ and ' $3 x$ ' \\
\hline
\end{tabular}


sion venue for these so called $18+$ students to do mathcollectively. By doing so, we believe the errors can be solved as they proceeded into calculus lessons. The courseware called CDiCL was built in 2005 using [22] significant learning and Hermann's Brain Dominance Model as its guide [9]. Figures 1-3 show its philosophy respectively.

In Figure 1, our brain has two parts called the left and the right side to cater for significant learning covering problem solving applications. This consumes basic knowledge and this integrates with human habits and behavior where as teachers we need to know how the students progress from time to time and by doing so the culture is we must inculcate the knowhow of learning to learn and relearn. So far, the left brain is heavily used by mathematicians and engineers while the musicians rely more on the right hand side of the brain. This is shown in Figure 2 below as explained in Hermann Brain Dominance model. In designing a courseware (over the internet), it is vital to incorporate 5 multimedia elements i.e., text, graphic, animation, audio and video plus interactivity to exploit the optimum ability of man Heinich et al [10]. Simultaneously the importance of doing the need analysis, idea planning, design structure and user interface. Next is the production of the courseware where all the above elements were integrated, testing the product and finally the final step in delivering the $\mathrm{CD}$ to the target clients i.e., certificate engineering students in PKB Polytechnic Kota Bharu. Looking at the processes, it is a big challenge for a teacher to produce a CD by himself alone since no one is a master of everything especially the content of the CD and using Flash MX2004 after coding [11].

In Figure 2, there is a need to bridge between interpersonal and logical skills of a man. This is done by organizing body of knowledge and experience a student has by discussing avenue between peers' collaboration and thus this produced a holistic and intuitive knowledge among future computer users/ workers.

The content of CDiCL was mainly pre-algebra, factorization and simplification at Form 2 level (age 14). Each topic has its own objectives explicitly put, quizzes and the CD concludes with three tests called Test1, Test 2 and Test3. Each test has a password to control the assessment and evaluation processes. Test 1 has 10 different questions and each one of them provides its own solution (if the user wanted to see), Test 2 has 10 question too but the courseware gave only 5 solved problem with all the solution path. This is to build some level of confidence among the users trying question from 6 to question number 10 . Finally Test 3 did not offer any solution at all except it came with the final score within 1 out of 10 marks. This is to create more confidence/ challenge as independent learners in future. To aid the users, the CD came with a dictionary called KAMUS CDiCL for English is used in the $\mathrm{CD}$. What was unique about this $\mathrm{CD}$ is that we incorporated the collaborative learning principles among the $\mathrm{CD}$ only, CL only and CDiCL only group while the control group carried traditional teaching and learning. From Felder [15], he claimed CL only group would come top in terms of gain score (difference between Post Test and Pre Test) and we thought CDiCL group, $\mathrm{CD}$ only group and the Control group would follow suit in terms of gain score. Bigger gain score reflect more success in doing the pre-algebra problems.

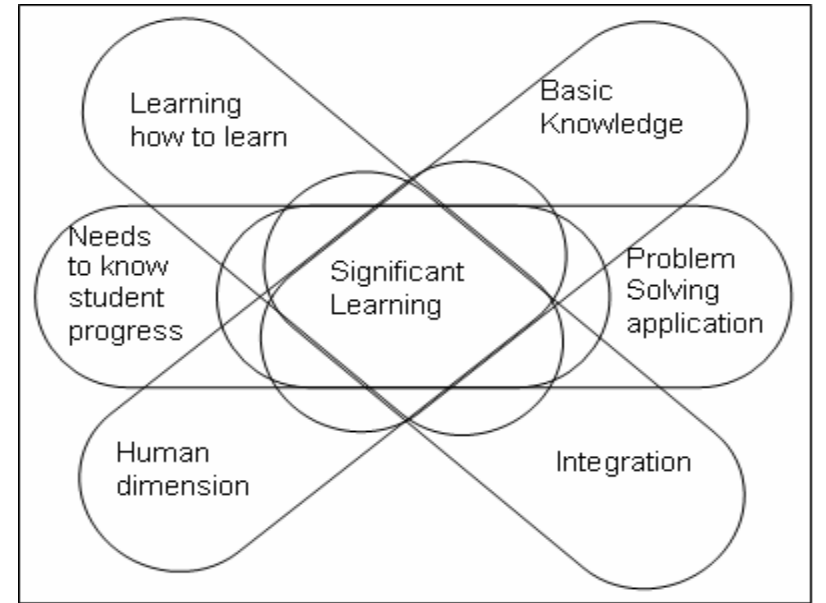

Figure 1. Effective Learning [22]

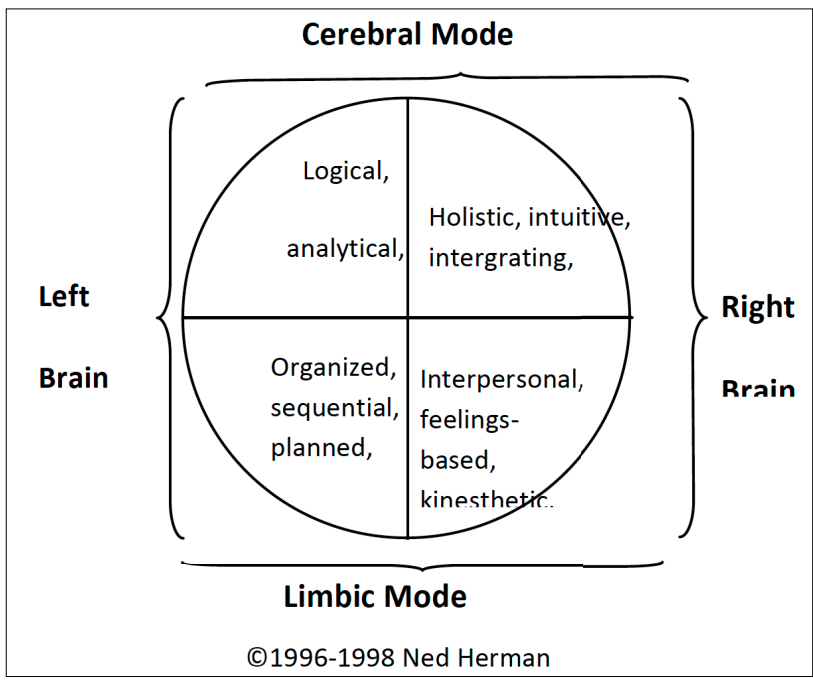

Figure 2. Hermann Brain Model [9]

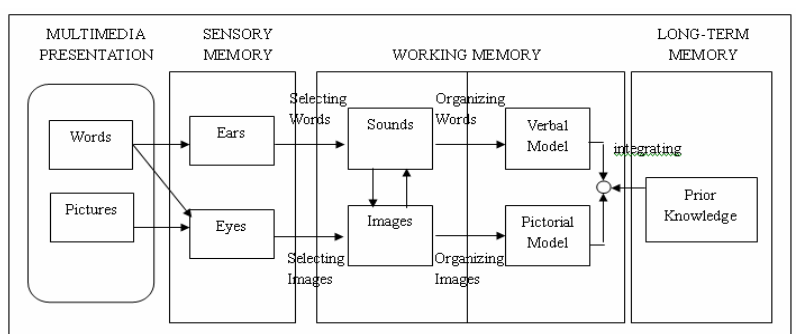

Figure 3. Splitting Effect between Words and Pictures modes [8]

When designing a courseware one's learning is subjected to three types of memory i.e. sensory memory, working memory and long term memory. This is in context with the splitting effect between two forms of input called visual and text modes in the learning processes. According to Mayer [8], there is a time difference between learning mathematics using text mode and visual mode. Bigger time is needed to create understanding among users if they read text only in mathematics as compared to mathematical problems with diagrams attached next to it on the question paper/ computer screen. Visualist loves to learn using pictures. There is economy of time between understanding the question and he start to strategize the solution to the mathematics problem. This is represented in Figure 3 . 
Figure 3 tries to show that human ability is fighting to catch the attention as far as learning is concerned from text and visual modes.

The research design called quasi-experimental was adopted in Figure 4.

In Figure 4, we saw 4 different groups. They took pre test in week 1 and posttest in week 8 . Between that period, they were led with different teaching and learning processes. Each team practiced different learning and teaching processes such as the $\mathrm{CD}$ group relied entirely on the courseware while CL only group practiced collaborative learning principles i.e., team discussions while solving word algebra problems. The CDiCL group took the middle path i.e., using CDiCL with CL discussions. The control group took the conventional style. Weekly the 4 groups participated for 1 hour only for 8 weeks consecutively. We predicted different learning outcomes from different learning processes. To develop CDiCL a method called ADDIE designing principles was used where it underwent analysis, design

incorporating story boards and media selection; development where programming using Flash MX2004; pilot testing at two different places and the actual Implementation and finally the evaluation.

With regard to Figure 5 below, the CDiCL was used in the Experiment stages where the participating students were guided using the courseware and the pre and post test were marked by the researcher and 2 other lecturers to kill biasness. 137 participating students volunteered in this research but some students pulled out in the middle of the experiment. At week 8, the Assessment and Evaluation were done. Below are few snapshots of a screen from the courseware.

In Figure 5, any screen has 4 quadrants. The left part has 2 quadrants and the right part has 2 quadrants too. Now, the bottom right quadrant showed an animation part in solving problem called Difference in Two Squares. If the student wanted some hints, the next upper right quadrant will provide hint and by doing so, hopefully the students can catch the clue / key towards getting correct answer. The animations have beautiful colors with it and visualist love many colours to learn effectively. Finally Figure 6 is the conceptual framework of this CDiCL. It is trying to convey that both information (text and visual) could be presented next to each other on the computer screen but before both information is relayed across the mind of the users, a second or two seconds was used to unload mental, cognitive overloading issues. The wiping of mathematical information happened at quadrant 3 of each screen. Mayer [8] ideas that the children cannot attend to two different things at one time was not popularly done nowadays as the trend is the mobile users are using their brain to catch many things at one time. Example motorists using mobiles while sitting behind their wheels!

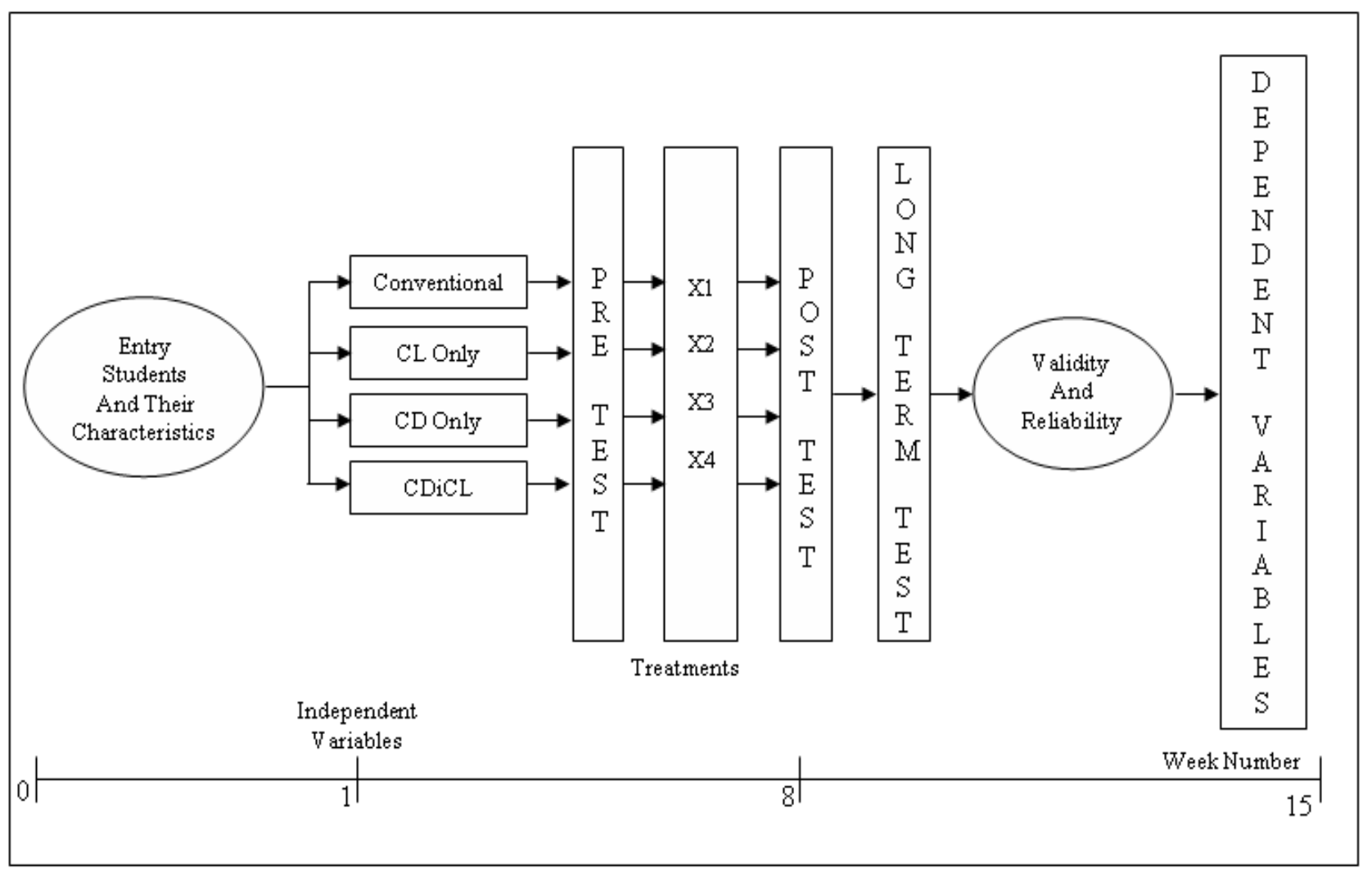

Figure 4. Research Method - Quasi Experiment groups that took part 
PAPER

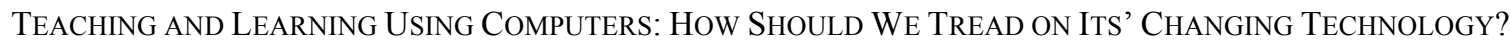
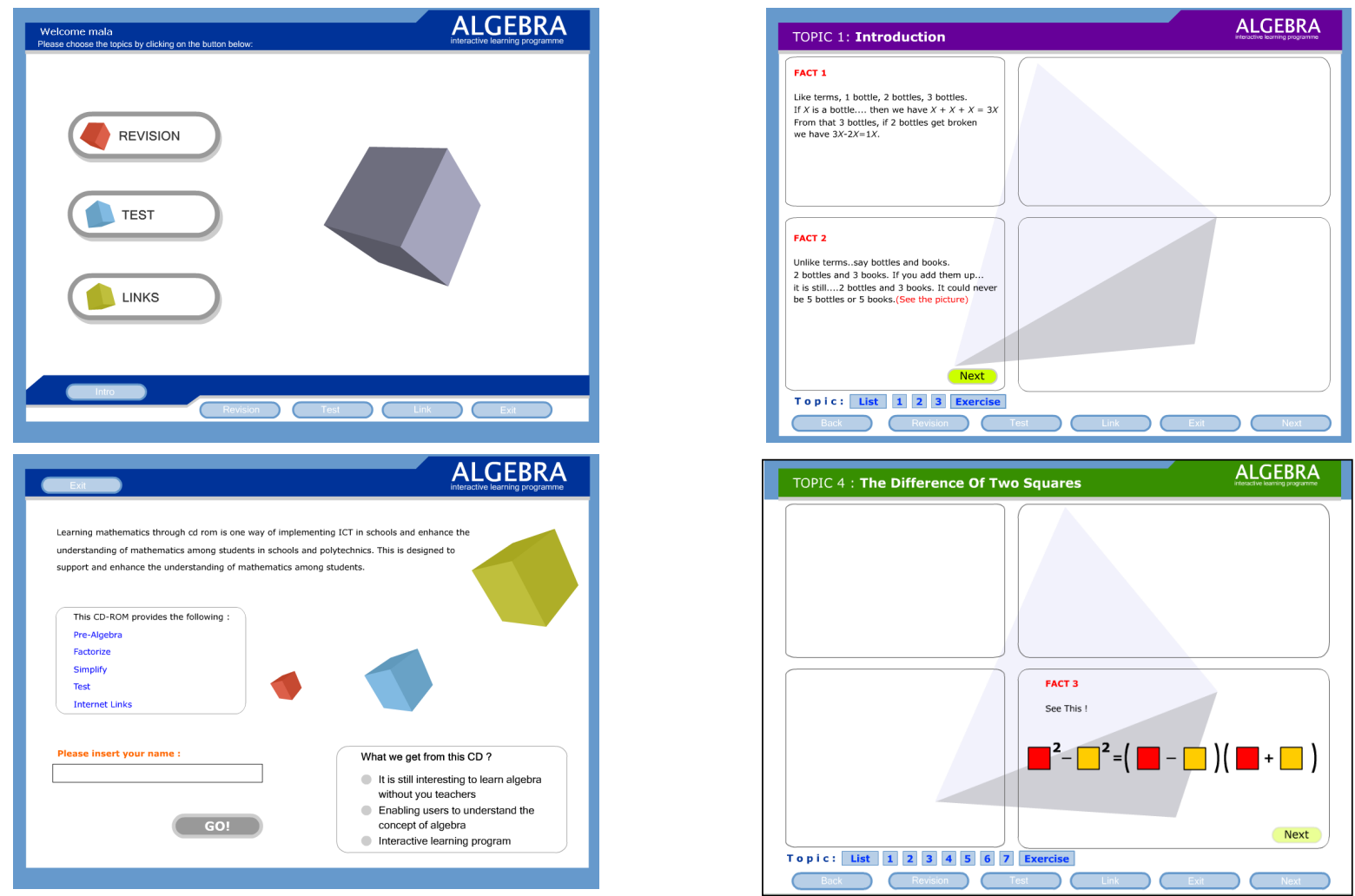

Figure 5. Two screens from CDiCL Courseware

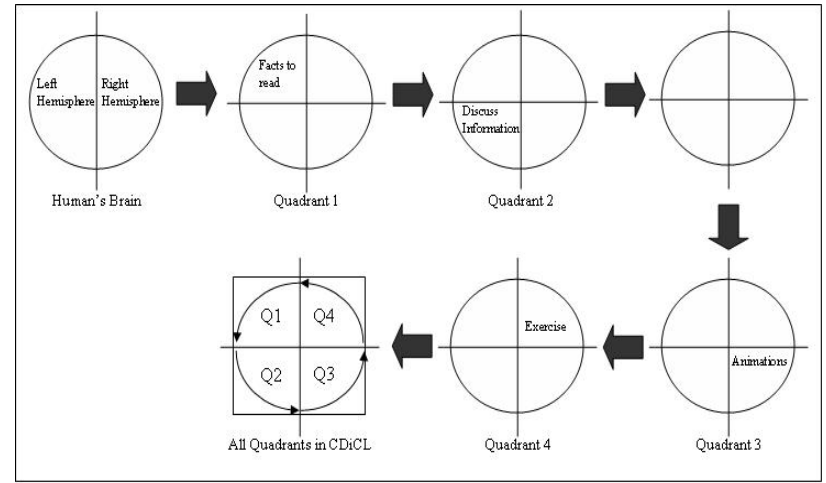

Figure 6. The Conceptual Framework

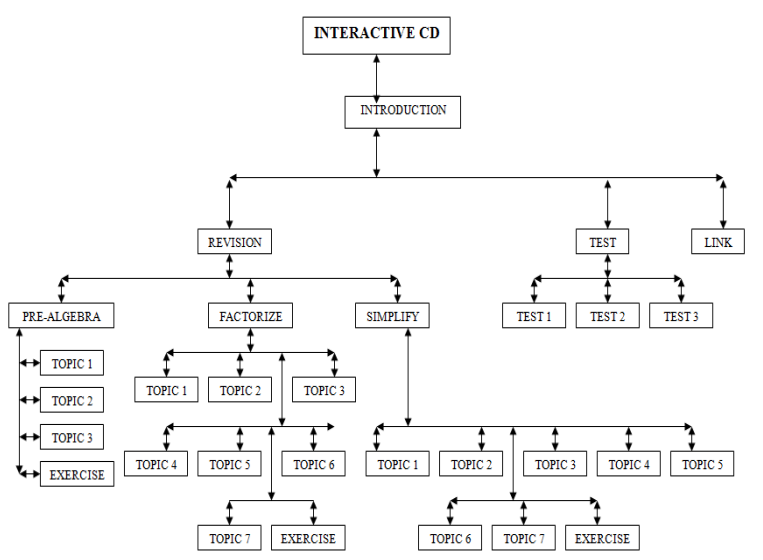

Figure 7. The Depth Structure in CDiCL
Figure 7 is the map of the contents as available in the CD. It started with the Introduction. Then it gave out the 3 modules called Revision, Test and Links. And from each module, for example REVISION, it gives some ideas on how many levels (breadth and depth) of each sub topic is will cover called pre-algebra, factorization and simplify. In order to maintain discipline, no student is allowed to get onto the test modules before they have covered all revision modules. This is enforced by the teacher himself. To conclude on this section, we have designed the material to be covered by 6 weeks (i.e., 6 hours of interactive learning).

\section{RESUlTS AND DisCUSSION}

The result of the experiment was put in Table II below. From the Table 1, it can be seen that there is a statistically significant difference between Group Type and Post Test since the value of 0.009 is less than the 0.05 level. This means that there is an impact of the different teaching methods in KBP as proven by the experiment. A Post Hoc Test revealed CDiCL can help the students in number problems, fraction and factorization only but solving word problem and simplification warranted higher critical thinking and problem solving skills. This is an area that needs further research.

Descriptive Statistics was CD only group obtained the highest gain score of 5.97 points, CDiCL got 5.62 points, Control group got 3.59 point and the last was CL only group with 1.98. From clinical interview some problem on team work, motivation and attitude had to be solved.

The second interesting point achieved was proven from Table III below. We checked the work by the students again after the Post Test and we were positive that some errors was successfully solved. 
TABLE II.

TESTS OF BETWEEN-SUBJECTS EFFECTS

\begin{tabular}{|c|c|c|c|c|c|}
\hline \multicolumn{6}{|c|}{$\begin{array}{l}\text { Tests of Between-Subjects Effects } \\
\text { Dependent Variable: Post Test }\end{array}$} \\
\hline Group Type & 331.546 & 3 & 110.515 & 4.032 & .009 \\
\hline Intercept & 1149.227 & 1 & 1149.227 & 41.930 & .000 \\
\hline Pre Test & 2385.997 & 1 & 2385.997 & 87.053 & .000 \\
\hline Error & 3206.801 & 117 & 27.409 & & \\
\hline Total & 21254.250 & 122 & & & \\
\hline Corrected Total & 6193.756 & 121 & & & \\
\hline \multicolumn{6}{|c|}{ a. $\mathrm{R}$ Squared $=, 482($ Adjusted R Squared $=, 465)$} \\
\hline
\end{tabular}

TABLE III.

FREQUENCY AND TYPES OF ERRORS SOLVED AMONG PARTICIPATING STUDENTS

\begin{tabular}{|c|c|c|c|c|c|}
\hline Level/type of errors & Carelessness & Negative sign symbols & change side - change sign & Transposing & Incorrect concept $31 / 3=3+1 / 3$ \\
\hline Pre Test & 34 & 59 & 39 & 67 & 12 \\
\hline Post Test & 27 & 43 & 30 & 43 & 7 \\
\hline Differences & 7 & 16 & 9 & 24 & 5 \\
\hline Percentage improvement & 20.5 & 27.1 & 23.1 & 35.8 & 41.7 \\
\hline
\end{tabular}

Table III shows that there are some improvements across the types of errors made when CDiCL was used within 8 consecutive weeks. CDiCL provided two things called firstly drill and practice and most importantly by collaboration, discussing over the terminal some understanding was achieved. It seems that incorrect concept like $3^{1 / 3}$ and $3 x$ was solved most impressively. The least success was careless mistakes. I opined that careless is part and parcel of learning if the students came into the examination hall a bit late than they are supposed to do. With limited time remaining and some personal difficulties, I think they rushed in answering the tests. However, the trend is some kinds of mistakes were carefully addressed in this work. And this is a big achievement because by solving this, the students can proceed doing calculus.

\section{A. Lessons learnt from the experience}

There were few interesting points learnt from building CDiCL. The ADDIE approach was taken as a guide. It covers Analysis, Design, Development, Implementation and Evaluation [8]. Writing the contents of the CD is creating the Story Board - the contents are put into the courseware using certain consistent format regarding colors, font size, interactivity, hypertext, and its objectives called implicit and explicit (Mohd Sazali, 2010). At the initial stage, the content must be examined by four people called Expert teachers in the subject area, Media Expert in recommending computer technology media and coding / scripting in Flash MX2004, Designer Expert gives advice on screen format, screen lay out and useful color from the screens, and Instructional Designer who looked things from the overall educational perspectives [12]. Rapid changes in technology and human habits using computer gadgets could turn their innovation into something obsolete within days thus de motivates many local developers. This happened when their product failed to catch the attention of their own students. An example is CDiCL courseware which has to compete with other courseware plus learning management system [19].

After spending 8 weeks in PKB, Malaysia - the teacher rubrics proposed is described in Table IV as follow:

TABLE IV.

PROPOSED TEACHER RUBRICS

\begin{tabular}{|c|c|c|}
\hline $\begin{array}{l}\text { Attainment } \\
\text { Levels }\end{array}$ & Description & Remarks \\
\hline 1 & $\begin{array}{l}\text { Switch on the computer correctly, get on the } \\
\text { internet without the teachers' help }\end{array}$ & Assuming that the computer laboratory is free from technical problems. \\
\hline 2 & $\begin{array}{l}\text { Be able to locate correctly which software, } \\
\text { courseware and which link to follow and they can } \\
\text { explain intelligently why they are doing that task } \\
\text { in the early part of a lesson and they can saved the } \\
\text { body of knowledge onto their own thumb drives } \\
\text { for future use at the end of the lesson per se }\end{array}$ & $\begin{array}{l}\text { The students are given a handout what to do in this } 1 \text { hour session in the computer } \\
\text { laboratory. They are explained the objective of todays' activities. Without this } \\
\text { objective, every student may be lost in cyber space. }\end{array}$ \\
\hline 3 & $\begin{array}{l}\text { After some time, given } 6 \text { questions the students } \\
\text { can solve at least } 3 \text { of the problem posed on the } \\
\text { lesson module say 'pre-algebra' }\end{array}$ & $\begin{array}{l}\text { There must be a target to achieve after } 1 \text { hour lesson. The teacher/facilitator must } \\
\text { learn to listen more to her students. By listening we create extra confidence } \\
\text { among computer users learning a subject content independently. }\end{array}$ \\
\hline 4 & $\begin{array}{l}\text { After some time, the students can solve at least } 4 \\
\text { questions posed on the lesson module called 'pre- } \\
\text { algebra' }\end{array}$ & $\begin{array}{l}\text { Everybody can ask, "is the objective met?" If not, they have to consult their } \\
\text { teachers. Try to listen more at some problem being discussed on the terminals. By } \\
\text { listening we can gather what was understood correctly by the students. }\end{array}$ \\
\hline 5 & $\begin{array}{l}\text { At the end of the lesson, the students can solve all } \\
\text { the } 6 \text { questions and /or explore harder questions as } \\
\text { given in the college algebra. }\end{array}$ & $\begin{array}{l}\text { What next after this lesson? By reflecting, the teachers can plan the most suitable } \\
\text { activity after this computer session or the student can decide whether to repeat the } \\
\text { lesson at other time or consulting her peers / teachers. Try and write } 2 \text { lines about } \\
\text { was gained from listening episodes between participants in this limited period of } \\
\text { time. }\end{array}$ \\
\hline
\end{tabular}


Without this sort of rubric, many teachers would be lost at being sidelined in a computer classroom [24]. Being a teacher, she wants to show her authority either physically or from the lesson content as well. Without authority, many teachers will be teaching using 'touch and go' concept i.e., they will spend as little time as possible at each terminal and of course there is some danger when many teachers lost their focus in thinking about the next lesson proper and what are the pertaining issues resulted from past lessons. This is because they failed to monitor how each student is doing in his/ her mathematics and science subjects.

\section{B. Discussion and recommendation}

Results showed there was statistically significant difference between groups using CD with collaborative learning principles as compared to the control (conventional learning). Other than that there were nine things that need highlighting: first, they like learning algebra in Malay language than English; second the CDiCL was best used within a short period of time say 15 to 20 minutes only, third they prefer pictures than text mode, fourth, they took longer time to acclimatize learning mathematics on the computers and fifth, it was important to build team work in order to get better learning outcome and six, the mean gain score between $\mathrm{CDiCL}$ and $\mathrm{CD}$ only was superior than CL only but the difference in gain score did not justify the cost of building the courseware as regard to development time including pilot testing at two important places. Seventh, motivation and attitude among the users must be addressed using IT products [26]. Eighth, team building in collaborative learning was a must since many schools cannot afford one computer to one user at a time and ninth they must know the objective of the experiment. From PKB experience, slow learners brought few baggage like poor learning attitudes and low motivation in doing experiments. They need more time to understand why CL was used in pre-algebra [15]. The hardest hurdle was they did not understand English very well in spite of 11 years exposure at primary and secondary schools. A lot of translation was done by peers and myself and this slowed down few learning processes. Moreover they were weak in negative signs such as " $x-2 x+2 x=5 x$ ". The CD went for assessment and evaluation including reliability and validity checkup. Reliability was $60 \%$ and usability was $80 \%$ [21]. Internal validity was obtained from Dr Mohd Farhan, a multimedia expert from UTHM. Assessment was done to check how the students were learning, how much they know about a particular topic and most importantly the feedback from both students and teachers. But it was important to be aware that serious public exams are mostly done by pen and paper while the learning processes at tertiary education - polytechnics and UTHM are mostly through LMS [13]. Future research could look at $100 \%$ learning and assessment directly from the online method. Usability Testing was done i.e., checking whether the students feel comfortable to use the courseware as planned by the researcher over a certain period in time plus the best time period in using it; why they were not comfortable learning using it; issues on the font size, screen design, problems from the novice users, language, response time between issuing of questions and answers between the computer and human interactions. The contribution of CDiCL to the body of knowledge was applying four specific quadrants of text plus picture modes through Hermann's Brain Dominance Model [8,9]. CDiCL applied both text and visual modes in learning pre-algebra with the incorporation of collaborative learning principles among weaker set of students in a polytechnic, Malaysia as a sample. CDiCL used 4 quadrants per screen beginning from the left with text and before the users see the pictures, the text contents were removed. This was to focus on solving mathematics using picture plus benefits derived from discussion with their peers [15].

\section{CONCLUSION}

This paper is about an experience derived from developing a courseware called CDiCL which was tried in a polytechnic, Malaysia. There are 137 students in 4 different groups from cohort 2006 from Certificate Engineering programs and the result was promising where many students using the CD only group and CDiCL group obtained more gain score than those from traditional and Collaborative Learning only group. For future work, CDiCL can be put on the web for online activities but research is still going strong on web matrix usability testing as suggested by Hazwani [7]. One of the problems is accessibility. With better teaching and proper guidance the students can learn much deeper using these tools for their future. As teachers we must equipped ourselves with correct question techniques. Possible research in future is this CDiCL must cater for random questions and there must be a program to catch which mistakes each student have made in each level of test. A link to certain dedicated web sites can be arrange so that after covering all the modules and question samples, the student can take more level of tests independently and at any time at post SPM level / tertiary educations. Enhanced research is rebuilding the modules as contained in $\mathrm{CDiCL}$ so that it can run online. Few works is suggested here such as there must be segmentation of question based on taxonomy Bloom and each student is alert towards what mastery level they have achieved at any instance. Next is to incorporate few types of attacks in solving any problem given out by the CDiCL because in mathematics, there are always few other methods proposed by other teachers from different countries and taking artificial intelligence is a good move since technology has improved a lot since the day we put a period to this article.

\section{ACKNOWLEDGEMENTS}

The author would like to express his gratitude to MOHE and UTHM, Vice Chancellor and its 2000 strong staff and thanks to the Polytechnic Kota Bharu PKB Principal and its' Department of Mathematics, Science and Computers staff in letting the CDiCL project to run among 137 students Certificate Civil Engineering and Certificate Mechanical Engineering Departments in academic session \# February 2006.

\section{REFERENCES}

[1] Mahathir M. Doctor in the house. Kuala Lumpur MPH 2012

[2] Khalid M.S, and Sulaiman Y. Experiences of e-learning at a Malaysian Technical University Network in Malaysia - is there any success? In Proceeding of Malaysian Technical Universities on Engineering and Technology (MUCET) Conference, 2012.

[3] MOE-Intel. Project Report MOE-Intel School Adoption Project Phase 1 Ministry of Education and Intel Malaysia. Kuala Lumpur: Educational Technology Division, MOE and Intel Malaysia, 2008. 
[4] Khalid M.S, Noor H.A.M. Teaching mathematics using CDiCLmaking sense from team work. Universiti Tun Hussein Onn Malaysia Press, 2012.

[5] Ishak A., Kasa Z., Selamat M.H., Samah B.A. Perbandingan pengajaran berasaskan multimedia dan tradisional ke atas Pencapaian Matematik dan Sikap Matematik di kalangan pelajar berisiko. Jurnal Teknologi Maklumat \& Multimedia, 2009, 6, 79-89.

[6] Dormehl L. The Apple Revolution. UK: Virgin Books, 2012.

[7] Hazwani R. Usability Metrics for Web Application Development. Unpublished M.Sc thesis Universiti Putra Malaysia, 2012.

[8] Mayer, R.E. Multimedia Learning. Cambridge: Cambridge University Press, 2001. http://dx.doi.org/10.1017/CBO978113 9164603

[9] Hermann N. The Creative Brain 2nd Edition. USA Quebecor Printing Book Group 1995.

[10] Heinich R., Molenda M. Rusell J.D., Smaldino S.E. Instructional Media and Technologies for Learning 7th edition. New Jersey: Meril Prentice Hall, 2002.

[11] Zin N.A.M., Zaman H.B. and Noah S.A.M. Penilaian Perisian Kursus Adaptif Multimedia (A-Maths) Berasaskan Stail Pembelajaran. Jurnal Teknologi Maklumat dan Multimedia, 6, 61-78, 2009.

[12] Ahmad W.F.W. Pembangunan dan keberkesanan perisian multimedia dalam pendidikan matematik untuk visualisasi corak geometric. PhD Thesis, Universiti Kebangsaan Malaysia, 2004.

[13] Sulaiman Y. Assessment Test, Anxiety and Achievement. Inaugural Talk 6/2011, Universiti Tun Hussein Onn Malaysia Press, 2011.

[14] Durell C.V. General Mathematics for Malayan Schools, 1-3. With answers, UK: Bells and Sons Ltd, 1960.

[15] Felder R.M. Nota Seminar UTM Cooperative Learning. Universiti Teknologi Malaysia, 2004.

[16] Khalid M.S. The effect of collaborative computer aided learning on learning pre-algebra among polytechnic students. Unpublished Ph.D thesis. Universiti Tun Hussein Onn Malaysia, 2010.

[17] Khalid M.S, Tan L.W., Herawan T. Road Traffic engineering applications in Mathematics Information Technology. Procedia Social and Behavioral Science, 2012, 59, 204-211. http://dx.doi.org/10.1016/j.sbspro.2012.09.266
[18] Khalid M.S, Maizam A, Wahid R, Sulaiman Y, Herawan T. The effect using an interactive multimedia courseware within a collaborative learning environment on the learning of pre-algebra concepts among pre-university students. Procedia Social Behavioral Sciences, 2012, 8, 571-579. http://dx.doi.org/10.1016/ j.sbspro.2010.12.079

[19] Khalid M.S, Maizam A, Wahid R, Sulaiman Y, Herawan T. The influence of teamwork using a multimedia interactive courseware in learning pre-algebra. Procedia Social Behavioral Sciences, 2012, 8, 654-662. http://dx.doi.org/10.1016/j.sbspro.2010.12.091

[20] TIMMS. Third International Mathematics and Science Study at the Eighth Grade. International Mathematics Report. Mullis, I.V.S., Martin, M.O., Gonzalez, E.J., Gregory, K.D., Garden, R.A., O'Connor, K.M., Chrostowski, S.J., and Smith, T.A. USA: Boston College International Study Centre, 1999- 2003.

[21] Tracer Study. Projek Kajian Graduan Politeknik Kementerian Pendidikan Malaysia bagi tahun 2003- 2005. Accessed: http:// www.politeknik.edu.my/websept07/Penerbitan/tracer_study_2006 /laporan_final_2006.pdf on 5 May 2009

[22] Fink, L.D. Creating Significant Learning Experiences: An integrated approach to designing College Courses. San Francisco Jossey Bass 2003

\section{AUTHORS}

Mohd Sazali Khalid is with the Faculty of Computer Science and Information Technology, University of Tun Hussein Onn Malaysia.

Edi Sutoyo is with the Department of Information System, University of Malaya, Kuala Lumpur, Malaysia.

Mungad is with the Department of Information System, University of Malaya, Kuala Lumpur, Malaysia.

Eka Novita Sari is with the AMCS Research Center Yogyakarta, Indonesia.

Tutut Herawan is with the Department of Information System, University of Malaya, Kuala Lumpur, Malaysia.

Submitted 06 June 2014. Published as resubmitted by the authors 19 August 2014. 